\title{
Finding time to make mistakes Jeff Adams
}

The place of the creative arts in the school curriculum is sometimes fiercely contested, as the recent struggles over the English National Curriculum have demonstrated. Nonetheless, their longevity as a staple ingredient in school curricula across the world demonstrates their enduring importance and the wide consensus over their value for general education. However, there has been a tendency of late for defenders of these subjects, in their arguments to justify their place in the curriculum, to resort to an economic justification rather than the social or moral grounds for their inclusion. This may seem at first sight to be reasonable, given the economic imperatives of western governments wedded to the supposed panacea of austerity, but a key problem with this strategy is that many of the economic arguments may prove false, or at least inadequate, compared to the powerful economic regeneration arguments put forward by advocates of the sciences or digital technologies.

A stark example of this was pointed out by Grayson Perry (2013), the British contemporary ceramist, in one of his Reith lectures, where he quoted from the British government's research into the benefits of having a degree qualification, which revealed that those studying degree courses in creative arts subjects are at the bottom of the economic table for future earnings potential (BIS 2011, p. 43; Grayson does go on to say, however, that this is should be a 'cause for celebration', since the enduring popularity of arts courses implies that people still want to go to art school to study despite the lack of an economic incentive, testament to the values of art education.)

Another, perhaps greater problem with the economic argument is the absence of the social case, of arts as a means for the improvement in the quality of life, or the case for the civilising principles inherent in cultural and creative education. Throwing our lot in with the economic argument also contains within it the inherent danger of losing the moral ground for creative practices in education. If market economics sets the terms of the debate, the economic hoops through which we have to jump, we may find that we are diminished - and demeaned - by jumping though them.

It may seem that we have little choice - these appear to be the rules of the game and we have to play by them. However, we could do worse than turn to Robin Alexander's (2009) case for the reform of the English primary school curriculum, where he argued that one of its problems is that it has been predicated on a $19^{\text {th }}$ century framework of competing subject disciplines, rather than a holistic concept of children's learning. The first principles of curriculum structure should not be the status of subjects or their lobbying power, nor their facilitation of economic imperatives; they should instead, as Alexander compellingly argues, be grounded in a consensus about the purpose and goods of education as a whole. Unless these first principles are established, we are doomed to a piecemeal curriculum, as has long been the case in state education in England at both primary and secondary levels. The broad goods of education: the social, collaborative, cultural and civilising effects, if not established securely, are too easily swept aside, only to be replaced by the technical, instrumental values imposed by the powerful but myopic and short term demands of market economics; these are rarely in the interests of children's learning or welfare, or in any belief in the common good of education (Adams 2013).

Perry (2013), in his lively and insightful Reith presentations on contemporary art practices, ranged over a number of the issues that affect arts education, in which he provided insights into some of the basic principles of the arts and of the curriculum as a whole. He drew attention to the problem of creative experimentation, or, to put it another way, of finding time to make mistakes, which is of great importance to the notion of pedagogy in the arts. As Perry put it:

The skip outside an art school is the repository of the ugliest objects on earth. They are not just ugly objects, they are ugly objects trying to be art; sort of like a potpourri of broken dreams. But that's how it should be: art college is a place to experiment, a place of unique freedom, a place to get it wrong, to make mistakes. The art critic Martin Gayford, he said this. He said, "Mistakes are as big a part of art 
as scholarship or truth. [...] So art history is a kind of long chain of Chinese whispers and I think that's the fascinating, brilliant thing about it - people get it wrong.

These refreshing comments, coming as they do from a practising contemporary artist, remind us of those other purposes of education, that once seemed so fundamental, prior to onset of economic and market dogmas. Consider Perry's description as a model of ideal practice: one can see immediately that this is anathema to the mantras of economic efficiency. According to Perry, students need plenty of time, from which they often produce mistaken ideas, some or all of which end up discarded; moreover, Perry argues that this model should be championed as a worthy ideal. And an ideal it is. Its strength is rooted in its very obtuseness, its inherent resistance to efficiency or standardisation, which I would argue is fundamental to cultural education. We might do well to argue like Perry, for the mistakes, the unproductive time, and the junked output at the end. Perhaps other disciplines could do with a skip outside the door to encourage creative play. Perry's comments are pertinent given this context of the increasing dominance of economic models of education across the world, and the corrosive effects that they can have on creative arts.

Others (i.e. Bruner 1983/2006) have commented on the importance of support for play and experimentation, and the mistakes that inevitably arise as a result of creative investigation and practice-based research. Perry goes on to develop this theme, describing the nature of being an art student:

The essential thing that one learns at art college is very difficult to condense. In many ways, one of the most important things is you're exposed to a kind of sensibility of what it's like to be an artist. You're a kind of trainee bohemian and you're there with fellow travellers on this journey with facilities and tutors on hand.

Perry emphasises the twin ingredients of artist/learner: acquiring an acculturated sensibility on the one hand, with the notion of fellow traveller, membership of a community that is bound together within these attuned sensibilities, on the other. In terms of curriculum, how can such mercurial and evanescent notions be accommodated? Is the very idea of curriculum, as an enduring, structuring entity, at risk here? What Perry is proposing seems to imply as much. After all, if the quality of the experience is determined by such idiosyncratic and changeable elements, the consistency routinely demanded by a curriculum is largely absent. If being educated in the arts is dynamic and transient, then its position and stability within a curriculum is open to question. This questioning is, however, a challenge to the concept of curriculum, rather than to the ephemeral nature of being artistic. Living with such ambiguities is a necessary part of arts education.

Time is also a key factor. If apportioning time is a basic function of the curriculum then time becomes a prized commodity; in the struggle for a liberal arts education such as that described by Perry, time is the most expensive component in the organisation of the curriculum. It is manifest in teacher presence in the studio or classroom, and the idea of paid staff presiding over time-consuming errors is problematic for any economic models of efficiency; it is to be avoided like a virus in the education hygiene. However, others view this particular pathogen, which infects the sanitised education project thorough its failures and errors, as a virtue. As Jay Coogan explains:

Though time is often in short supply in demanding educational environments, making temporal space for creativity should be consciously integrated as part of the educational experience. Time often plays a key role in developing original outcomes and finding unique solutions. To be creative, you cannot be hurried, as there is often a long period of nurturing before creative ideas begin to gel. Developing as an artist or designer requires mental space to allow for intended or unexpected discoveries. An environment that encourages time for solitude interlaced with time for intense interaction is optimal. (Jay Coogan, quoted in Hill, 2012) 
The arguments here are in many ways typical of those that arts advocates make, and are similar, if less colourfully expressed, to those of Perry: time is not only necessary but needs to be flexible and extendable; the results of any inquiry are not only unpredictable but may not be fruitful, at least apparently, and even if they are, they are probably going to be difficult to quantify, in any obvious way that might conform to a standardised assessment pattern. What we have is a series of learning features which are considered virtues by creative practitioners, but are antithetical to other disciplines sharing the same curriculum.

How can such nebulous characteristics be reconciled into a curriculum, without destroying the very features that make a creative education valuable? The solution might be to remake the curriculum in the image of the arts; that is to infuse the curriculum with the features and characteristics of creative practice, and in doing so create the conditions favourable to the study of the arts. The establishment of space and time for the arts, not merely as an adjunct or foil for to the technologies and sciences, but as a prerequisite, may be the necessary ground for which any learning or study can take place.

Asking if it's possible to reconcile creative practices within a single organising instrument is not the only question that we need to address. We should also consider how we can find ways to accommodate ambiguity, how we can live with the irreconcilable, and how we can resist the desire to homogenise. This is less of a solution, and more of a recommendation for the persistence of negotiation; perhaps it is in the maintenance of the debate, the continued examination of what it is to learn though imagination and creativity, of what it means to teach through the arts alongside others who think differently, that a detente of sorts may be found.

\section{References}

Adams, J. (2013) The Artful Dodger: Creative Resistance to Neo-Liberalism in Education, Review of Education, Pedagogy and Cultural Studies, Vol. 35, No.4, pp. 242-255.

Alexander, R. (Ed.) (2009) Children, their world, their education: Final report and recommendations of the Cambridge Primary Review. London: Routledge

BIS (Department for Business Innovation and Skills, British Government, 2011) The returns to higher education qualifications, at https://www.gov.uk/government/uploads/system/uploads/attachment_data/file/32419/ 11-973-returns-to-higher-education-qualifications.pdf (accessed 25 November 2013)

Bruner, J. S. (1983/2006) In search of pedagogy volume II: The selected works of Jerome S. Bruner. Oxon: Routledge

Hill, P. (2012) In The art of the matter, Times Higher Educational Supplement, 19 January 2012, http://www.timeshighereducation.co.uk/418698.article (accessed 18 November 2013)

Perry, G. (2013) Grayson Perry: I found myself in the art world, Reith lectures 2013, BBC Radio 4, at

http://www.bbc.co.uk/iplayer/episode/b03g9mn1/The Reith Lectures Grayso n_Perry Playing to the Gallery 2013 I Found Myself in the Art World/

(accessed 25 November 2013) 